\title{
Undoing Time: The Life and Work of Samuel Beckett
}

\section{Thierry Robin}

\section{OpenEdition}

1 Journals

Édition électronique

URL : http://journals.openedition.org/etudesirlandaises/4756

DOI : 10.4000/etudesirlandaises.4756

ISSN : 2259-8863

\section{Éditeur}

Presses universitaires de Caen

\section{Édition imprimée}

Date de publication : 15 décembre 2015

Pagination : 162-163

ISBN : 978-2-7535-4366-9

ISSN : 0183-973X

\section{Référence électronique}

Thierry Robin, "Undoing Time: The Life and Work of Samuel Beckett », Études irlandaises [En ligne], 40-2 | 2015, mis en ligne le 15 décembre 2015, consulté le 23 septembre 2020. URL : http:// journals.openedition.org/etudesirlandaises/4756; DOI : https://doi.org/10.4000/etudesirlandaises. 4756

\section{(c) (ஒ)(}

Études irlandaises est mise à disposition selon les termes de la Licence Creative Commons Attribution - Pas d'Utilisation Commerciale - Partage dans les Mêmes Conditions 4.0 International. 
the way in which the realities of the Troubles and of the North's peripheral nature are shown to intersect with and complicate the usual challenges faced by actors of the music world: efforts such as organizing a festival, finding a venue, managing a band, going on tour or dealing with the barons of the music industry become significantly more difficult when one has to deal with sectarian tensions, hostile local authorities, security forces and paramilitaries. But this is no grim account of the Northern conflict: on the whole, Richard Sullivan has managed to capture Terri Hooley's buoyancy and charisma - no easy feat when considering his idiosyncratic speech pattern and the fact that his anecdotes are best told in person - but what truly brings Hooley to life are the short interstitial testimonies written by a range of people associated with the North's music scene, which act as a chorus and as a counterweight to the larger-than-life voice that sometimes threatens to become overpowering, and which remind the reader that Hooleygan is at its heart a love letter to music and to Belfast.

Tim Heron

Université de Reims-Champagne Ardennes

Jennifer Birkett, Undoing Time: The Life and Work of Samuel Beckett, Sallins, Irish Academic Press, 2015, XII + 226 p., ISBN: 9780716532903.

This new monograph by Jennifer Birkett, Emeritus Professor of French Studies at the University of Birmingham, explores the paradox inherent in the concept of "undoing time" in Beckett's work. While "doing one's time" initially refers to jail slang to describe prisoners waiting for the moment when they are released, with Beckett, every man has to do his time on Earth, oscillating between tedium and suffering, waiting more or less eagerly or consciously for the liberation that is death, like Krapp's "intense longing for death: 'drowned in dreams and burning to be gone" in Krapp's Last Tape, (132). Birkett though is not satisfied with this univocal claustrophobic dark reading of Beckett. She highlights the converse process of undoing time in his writings. To do so, she looks chronologically, in seven chapters, at Beckett's poetry, novels, shorter prose, theatrical works and then again shorter dramatic works to identify a refining process in Beckett's treatment of time and failure. Her book investigates Beckett's collaboration with the BBC Radio and Television - in chapter 7 - as well as his bash at cinema with Alan Schneider in Film in 1967.

Negation, substraction, alongside a fierce lucid sense of humour - as in Molloy or Endgame - are Beckett's best known weapons. These, Birkett posits, allow 
readers to "enter $[\ldots]$ into a different understanding of not what, but how it is to be human" (1). By writing about futility and exhaustion, Beckett defeats, "dilates" time, turning failure into play, impasses into inner journeys, even verging on the lyrical towards the end of his life as in Ohio Impromptu.

Though chapter one - inevitably dealing with the Joycean father figure and the coda focus more on biographical data, quoting from James Knowlson's work, the great bulk of Birkett's study aims to outline Beckett's singular innovative stance on the postwar literary scene. She shows the enduring Irishness of Beckett's work despite his aversion to realist details. The notion of gender often proves apt. As Birkett notes "the figure of the Mouth [in Not I] was [...] inspired by the many bent old women who staggered along the country roads of Ireland" (146). She pays special attention to women characters in plays, as in Happy Days, Footfalls or Not I and insists on the real women Beckett encountered throughout his life, from Suzanne Déchevaux-Dumesnil - his wife -, Barbara Bray - BBC script editor, translator, critic and lover - to Billie Whitelaw - his "perfect actress". Finally, this study focuses on reception, especially theatrical reception, developing the taunting bourgeois figure of the "thousand-arsed Spectator" (123) that Beckett disliked but gradually grew indifferent to, concentrating on the increasingly choreographic minimalist forms he could give to his work.

In this thorough yet concise academic survey, the reader will find a readable introduction to Beckett's philosophy. Life is nothing doing, "even dying is a form of bluff" (128).

Thierry RoBIN

Université de Brest, UBO

Jérôme AAN DE WIEL, East German Intelligence and Ireland, 1949-90: Espionage, terrorism and diplomacy, Manchester, Manchester UP, 2015, XIv + 313 p., ISBN 9780719090738

En 1989, à la veille de l'implosion de la République démocratique allemande, sa police politique - la "Stasi » - comptait plus de 91000 agents, et si ses archives furent partiellement détruites en 1990, il en demeure encore $158 \mathrm{~km}$ linéaires, sans compter les milliers de sacs de documents déchirés que des volontaires recomposent petit à petit. Les anciens de la Stasi ont beau jeu d'affirmer que tout cela n'était qu' "un jeu d'enfant " comparé aux pratiques de la NSA mises en lumière par Edward Snowden (p. 107). Sans chercher à minimiser les dérives affolantes des services de renseignement à l'heure d'internet et de la lutte contre le 